\title{
ICT: an aid to inclusion? Reflections on the potential of ICT for the changing role of the special school
}

\author{
Chris Abbott and John Galloway \\ Department of Education and Professional Studies, King's College London, Franklin-Wilkins \\ Building, London, SE1 9NN, United Kingdom.chris.abbott@kcl.ac.uk
}

SEN Centre, 85 Harford Street, London, E1 4PY, United Kingdom. jgalloway@towerhamletsclc.org.uk

Key words: Agent of Change, Classroom, Disability, Equity, Special Needs

\begin{abstract}
Inclusion has been an aim for many national education systems but progress has, in some countries, been slow or halting. Information and Communication Technology (ICT) has been a key factor in the greater inclusion of individuals with special educational needs, either by enabling them to communicate more readily and widely, or by assisting them to overcome their learning difficulties. The paper examines the extent to which ICT can contribute to social change by redefining the role of the special school. A case study of one special school, given a range of support and resources, attempts to discover the potential of ICT in this area. If a school is provided with appropriate hardware and software, training in ICT for all teachers, and the support of a specialised advisory teacher, can that school develop valuable resources for the wider education community? How should these resources be disseminated? The progress of the case study is described through the use of semi-structured interviews, diaries and commentary, and a number of emerging issues are identified.
\end{abstract}

The original version of this chapter was revised: The copyright line was incorrect. This has been corrected. The Erratum to this chapter is available at DOI: 10.1007/978-0-387-35663-1_34 


\section{INTRODUCTION}

This paper describes a small-scale intervention case study which took place over nine months in an inner-city area of the UK and relates the findings to wider issues of inclusion, ICT and social change.

Over the last twenty years most education systems in Europe, the USA and Australasia have begun to implement some form of inclusive education. In a number of cases, this has meant providing access to education where none was previously available; in others the focus has been on extending access to education to groups not previously offered this opportunity.

Current UK policy is firmly aimed at inclusion, although precisely what this means can be a matter of interpretation. Inclusion has often been in conflict with other policies, especially those regarding school standards and achievement (Abbott 2001). Despite this, government policy in the UK has been only one driver towards inclusion, with individuals and organisations deploring the methodology of separate provision - even the 'pathologising' of children (Billington 2000).

With the implementation of the UK National Curriculum in 1988 it was expected that some students with severe learning difficulties would be disapplied from the curriculum. In the event, this rarely took place and the National Curriculum, and access to it, became an entitlement issue. At the same time, special school closures continued. One mixed needs school often replaced three or four alternative and specialised schools or units. The mixed needs model is clearly less expensive. Despite the closures being particularly marked in areas with historical reasons for greater special education provision (such as London), the percentage of UK children in separate provision has changed only slowly. In $1978,2 \%$ of the school population was in special schools; by 2000 this had dropped to $1.3 \%$.

Where special schools have survived, they have often changed their role and adopted new and innovative practices. Our case study examines one such school, catering for students who attend full time from the ages of 2 to 11 years and who have severe or profound and multiple learning difficulties. The school, which we will call Eastville, is an award-winning, purpose-built school - barely five years old. It currently has 71 pupils and a staffing ratio of almost one to one. Teaching staff are supplemented by teaching assistants and supported by other services including speech and language therapists and physiotherapists.

Eastville School is in an inner city area which has pockets of severe deprivation punctuated by expensive housing for the professionals who work in the expanding service industries. Over 50\% of Northstone LEA's school population are from ethnic minorities. 


\section{THE CONTEXT - ICT AND SPECIAL EDUCATIONAL NEEDS}

It has long been recognised (McKeown 2000, Abbott 2000a, 2000b, 2002) that ICT can play a major role in assisting students with special education needs (SEN). It can enable them to communicate with others, become fully literate and learn more effectively. However, the ICT orders in the UK National Curriculum may not be accessible to all students with SEN, especially those who are likely to spend most of their school career working towards the lowest levels of the curriculum.

For this reason, guidance was produced (QCA 2001) to provide exemplar and other material in ICT and all other subjects with this target group in mind. The guidance included performance descriptions known as the $P$ scales or $P$ levels offered for performance across and within subjects. They describe performance before Level 2 of the National Curriculum in eight stages, from $\mathrm{P} 1$ to $\mathrm{P} 8$. For example, $\mathrm{P} 4$ for ICT reads:

"Pupils intentionally make selections to communicate meanings. They know that certain actions produce predictable results, and that ICT can be used to control objects, events and aspects of the environment." (QCA 2001: 19)

It has been suggested (Colwill and Peacey 2001) that the National Curriculum is not a curriculum at all and that the curriculum delivered by the school is what matters. It is good to see an emphasis on teachers and schools "determining and constructing their own curriculum" even if that might not be how some of those teachers see it.

"Throughout the ten years of the National Curriculum many teachers working with pupils with learning difficulties have adapted the National Curriculum for use in their situations. There has been no commonly agreed approach to the adaptations and no articulation of a curriculum model either to assist schools in curriculum development or to provide a blueprint against which schools' performance can be judged." (Colwill and Peacey 2001: 122)

The tension would seem to be between the "commonly agreed approach" and the teachers who are busily determining and "constructing their own curriculum". Initial reactions from Eastville School were not particularly positive. 
"Well, we've started looking at this, the Advisory Teacher and me, but we've also gone back to the actual National Curriculum. We've actually been using that. And we actually in the end found that more of a help than this." ICT Co-ordinator Month 2

\section{WHAT HELPS? DESCRIPTION OF THE CASE STUDY}

Eastville, like all schools in the UK, has received considerable extra ICT resources since 2000 through the Department for Education and the Environment (DfEE) (now Department for Education and Skills (DfES)) Standards Fund. All its computers have been purchased in the last five years, since the school opened. It has thirteen computers for curriculum-oriented work, a well-equipped sensory room, and a new music room with a skilled part-time technician. So far, funds have gone into increasing the available technology: in the next financial year funds will have to begin to address the problem of replacing outdated equipment.

The school has also been provided with a generic suite of software (Infant Video Toolkit - 2Simple Software), originally designed for younger children, which could offer an appropriate resource for older students with severe learning difficulties. Experience in the classroom and training they have received has made the teachers clear about what makes software appropriate for their students.

"something that's visually not cluttered even if the actual operation of the program is relatively simple." Year 5 Teacher Month 2

Eastville School, like all UK schools, received staff in-service ICT training supported by the New Opportunities Fund (using proceeds from the UK National Lottery). This training was purchased from a prescribed list of specialist SEN providers and staff considered the training was of value.

"Lots of good ideas... especially as I was currently new to IT and special needs. But I think I need more. Well I know I need more..." Year 4 teacher Month 2

"What I found very useful was the huge wad of notes and information. I haven't read it all but it's quite useful as a resource to go to..." ICT Coordinator Month 2

The school also had access to the equivalent of nine days of support from a designated ICT and SEN advisory teacher. This was given as extra 
training, classroom support and by working with individual teachers. A particular problem for a school offered this kind of support is deciding how to make best use of it.

"I think spread out regular... But say you're working on a particular program (having an Advisory Teacher) gives you... time to work with the children, especially this type of child that may need a lot of practice." Year 5 teacher Month 2

Eastville School therefore has the four components needed to enable effective teaching of and with ICT:

- In-service training for teachers.

- Appropriate software.

- Advisory teacher support.

- Guidance documents and resources for curriculum delivery.

The case study examined the effect of each of these support mechanisms on the process of developing an ICT Scheme of Work (SoW) in the school for Key Stage 2 (children aged from 8 to 11 years). Semi-structured interviews with two classroom teachers and the school's ICT Co-ordinator took place at the beginning and end of a nine-month period during one school year. The Advisory Teacher and the Co-ordinator kept diaries of progress and, during early meetings in Month 1, they developed the initial SoW. They quickly realised that a suitable style to adopt would make use of the phrase "All/Most/Some pupils will be able to" - based on terminology in curriculum documents (QCA 2001).

There were also discussions about the use of e-mail, the pupils' understanding of e-mail, the needs of 'switch' users and the usefulness of existing resources. During Month 2 the focus was on the use of existing materials alongside the school's Development Plan and other internal documents. It was decided that ICT would be taught as a discrete subject at Key Stage 1 (KS1), although this age-group had not formed part of the original plans. Much discussion around mechanisms for sharing useful Web resources resulted in a mix of training sessions for staff and guided use of the staffroom computer and its book-marked sites. A group of staff evaluated Infant Video Toolkit and concluded that many elements of the package would meet pupil or staff needs.

Next, activities leading to Logo became a focus and a variety of radiocontrolled toys were purchased to develop concepts of control, direction and speed. During Month 3, school responses to symbol e-mail were discussed with the Advisory Teacher and further sections of the SoW were completed. Aspects of the use of one computer in a classroom were discussed and different formats of lesson plans were considered. 
By Month 4, the ICT Co-ordinator had developed lesson plans for all three areas of the SoW and all four years of KS2 - a much greater achievement than had been expected. The Co-ordinator also produced an ICT plan highlighting activity for the remainder of the academic year. She planned twilight training sessions to introduce the lesson plans and asked all teachers to try out some of the lessons by Month 7. At this point KS1 was added to the SoW and thus a comprehensive programme covering the whole of primary education from 5 to 11 years was developed. By Month 8 , the school had begun to look at existing ICT assessment schemes aimed at people with learning difficulties. The SoW was now tied closely to the $\mathrm{P}$ level guidance. It was agreed that it would be introduced from the beginning of the following academic year (Month 11) following ratification by the School Governors.

\section{ISSUES ARISING FROM THE CASE STUDY}

A number of issues have arisen. Many have been identified before (Abbott and Cribb 2001) and the case study provides further evidence.

\subsection{Individual schools versus national initiatives}

One issue relates to the effects of individual school initiatives versus what might be termed national diktat. When many older teachers began their careers they had almost total control over the curriculum taught in their classrooms and developed materials accordingly. An associated issue relates to resources developed for teachers rather than by them, and the extent to which these resources can be used effectively by the target group. It is striking to note the increased level of confidence shown by the staff at the end of the case study period. The ICT Co-ordinator had recognised that printed materials can only be useful as a starting point.

\subsection{Isolated position of special schools}

Special school isolation has been identified as part of the emerging research agenda around special schools (Abbott \& Cribb 2001). At Eastville isolation was less marked than might have been the case without the presence of the Advisory Teacher and his ability to help staff locate themselves within their Local Education Authority and the wider SEN community. ICT and the World Wide Web can help schools avoid this isolation (Abbott 1998, Galloway 2002). Indeed, the ICT Co-ordinator, who 
is also the school's Early Years Co-ordinator, began working one day a week at a local primary school. This enabled a changed working relationship between school and LEA advisor, since both individuals now work alongside each other to support this mainstream school.

"(Eastville) as a school in principle is very happy to share its schemes of work with anyone and the idea is that at some point it'll be on the website and people will be able to download them." ICT Co-ordinator Month 9

The placement was a recognition of the teacher's experience in the area of Early Years and ICT, and is another indicator of the ICT-related changes in working practice that are blurring the boundaries between mainstream schools. However, at the local level the lack of a special school ICT Coordinator network, common in the mainstream school system, continues to cause concern.

\subsection{Role of resources in curriculum change}

The usefulness of documentation such as the P-scales is clearly a key issue. They represent the newest resource available to the school and have been issued for all subjects. Perhaps the most significant positive outcome recorded by the participants was that they were able to decode the P-scales sufficiently to understand them fully and make appropriate decisions about their usefulness. Staff at Eastville and other special schools are also aware that, in future, they will be asked to set targets for all their students in some subjects. Our case study examined the extent to which the varying support considered might assist in this process.

\subsection{From long-term to short-term placements}

A further development in the changing role of the special school was the rapid development of short-term placements at Eastville. Towards the end of the project almost $40 \%$ of the school roll consisted of short term placement pupils in the nursery, most of whom were expected to progress to mainstream schools after a relatively short time in special education. There are now as many Early Years pupils at the school as there are in Key Stage 2 . The expectation was that the needs of these very young children would be addressed and that Eastville would prepare them for a mainstream placement. 


\section{CONCLUSION}

This paper has shown how ICT is involved in the process by which special schools could move more quickly to a wider resourcing role than most currently play. If one special school is able to use these resources and support mechanisms to develop an ICT scheme of work, could it support other schools and share what it has created? Must every school go through the same process, each in their separate and exclusive settings? Can the process used to develop a scheme of work in one curriculum area act as a model for other areas?

It is our assertion that ICT has a key role to play as an agent of change and to enable special schools to take on their role as a resource for the mainstream. This assertion is not based on any simplistic technological determinism, but through a combination of the status of ICT as a new subject, its power to offer crucial support for those with SEN and, not least, its intrinsic ability to attract funding from governments and education authorities.

\section{REFERENCES}

Abbott, C. (1998) Making the Web Special, King's College/Institute of Education, London.

Abbott, C. (2000a) ICT: Changing Education, RoutledgeFalmer, London.

Abbott, C. (Ed.) (2000b) Symbols Now, Widgit, Leamington Spa.

Abbott, C. (2001) Special educational needs: Becoming more inclusive, In Becoming a Teacher: Issues in Secondary Teaching (2nd ed.), J. Dillon, and M. Maguire, (eds.), pp. 192-202, Open University Press, Buckingham.

Abbott, C., and Cribb, A. (2001) Special Schools, Inclusion and the World Wide Web - the emerging research agenda, British Journal of Educational Technology, 32 (3), pp. 331342.

Abbott, C. (2002) SEN and the Internet: Issues in Inclusive Education, RoutledgeFalmer, London.

Billington, T. (2000) Separating, Losing and Excluding Children: Narratives of Difference, RoutledgeFalmer, London.

Colwill, I., and Peacey, N. (2001), Planning, teaching and assessing the curriculum for pupils with learning difficulties: curriculum guidelines to support the revised National Curriculum, British Journal of Special Education, 28 (3), pp. 120-122.

Galloway, J. (2002) Developing an LEA website to support the inclusion process. In SEN and the Internet: Issues in Inclusive Education, C. Abbott (ed.), RoutledgeFalmer, London.

McKeown, S. (2000) Unlocking Potential: How ICT Can Support Children with Special Educational Needs, The Questions Publishing Company Ltd. Birmingham.

QCA (2001) Planning, teaching and assessing the curriculum for pupils with learning difficulties: Information and communication technology, Qualifications and Curriculum Authority, London. 